Psychiatric

Bulletin

Volume 14 Number 12

December 1990

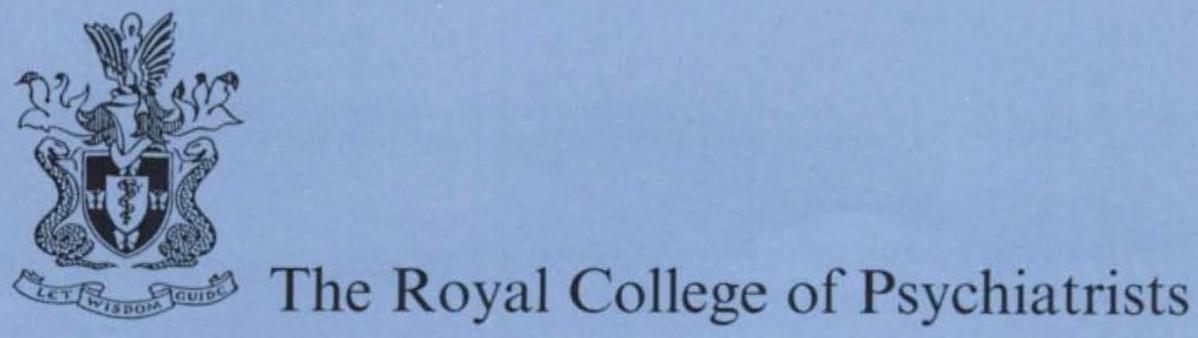




\title{
Psychiatric Bulletin of the Royal College of Psychiatrists
}

\author{
Editors: Alan KerR and Greg Wilkinson \\ Manager: ELAINE MiLLEN
}

Assistant Editor: Rosalind RAMSAY

\section{Notice to contributors}

The Editors welcome articles of general interest to psychiatrists. Two thousand words is a good length; however, longer articles will be considered. Tables, diagrams and extended references should generally not be included. Please submit three copies, typed double-spaced, and using the Harvard system of referencing, as in The British Journal of Psychiatry. Correspondence on subjects of topical interest is also welcome. Contributions are accepted for publication on the condition that their substance has not been published or submitted for publication elsewhere. The views expressed in articles published in the Psychiatric Bulletin (except official College material) are the author's own and do not necessarily represent College policy.

The Psychiatric Bulletin of the Royal College of Psychiatrists is published monthly by the Royal College of Psychiatrists, 17 Belgrave Square, London SWIX 8PG. All contents (C) Royal College of Psychiatrists, 1990, unless otherwise stated.

ISSN $0140-0789$

Printed in Great Britain by Henry Ling Ltd, at the Dorset Press, Dorchester, Dorset 